\title{
Persistence of Human Pathogens in Manure-Amended Australian Soils Used for Production of Leafy Vegetables
}

\author{
Jennifer Ekman ${ }^{1, *}$, Adam Goldwater ${ }^{1}$, Mark Bradbury ${ }^{2}$, Jim Matthews ${ }^{3} \oplus$ and Gordon Rogers ${ }^{1}(\mathbb{D}$ \\ 1 Applied Horticultural Research, Biosciences Building, 1 Central Avenue, Eveleigh, \\ Sydney, NSW 2015, Australia; adam.goldwater@ahr.com.au (A.G.); gordon@ahr.com.au (G.R.) \\ 2 ARC Training Centre for Food Safety in the Fresh Produce Industry, \\ School of Life and Environmental Sciences, University of Sydney, LEES Building, Chippendale, \\ Sydney, NSW 2006, Australia; mark.bradbury@sydney.edu.au \\ 3 Sydney Informatics and Data Science Hub, University of Sydney, Queen St, Chippendale, \\ Sydney, NSW 2006, Australia; jim.matthews@sydney.edu.au \\ * Correspondence: jenny.ekman@ahr.com.au
}

check for updates

Citation: Ekman, J.; Goldwater, A.; Bradbury, M.; Matthews, J.; Rogers, G. Persistence of Human Pathogens in Manure-Amended Australian Soils Used for Production of Leafy

Vegetables. Agriculture 2021, 11, 14. https://doi.org/10.3390/

agriculture11010014

Received: 30 November 2020

Accepted: 22 December 2020

Published: 28 December 2020

Publisher's Note: MDPI stays neutral with regard to jurisdictional claims in published maps and institutional affiliations.

Copyright: (C) 2020 by the authors. Licensee MDPI, Basel, Switzerland. This article is an open access article distributed under the terms and conditions of the Creative Commons Attribution (CC BY) license (https: / / creativecommons.org/ licenses/by/4.0/).

\begin{abstract}
Incorporation of manures into soil can add nutrients, improve soil structure and enhance biodiversity, thereby improving the sustainability of vegetable production systems. Unfortunately, manures can also potentially contain human enteric pathogens. To reduce the risk of contamination, Australian guidelines recommend a withholding period of 90 days between manure application and harvest for high-risk products such as leafy salad greens. Our study examined the appropriateness of these guidelines under conditions replicating those on a commercial vegetable farm. Cow manure and poultry litter with/without addition of non-pathogenic strains of Escherichia coli (E. coli), Listeria innocua and Salmonella sv. sofia were added to sandy and clay loam soils typical of those used to grow vegetables. Bacterial populations were monitored in the soil and on crops of cos lettuce during spring (A), summer (B) and autumn (C) trials, with testing conducted by a commercial laboratory. Significant declines in E. coli occurred within 6 to 16 days in all trials. Modelling indicated that $E$. coli populations would be at or close to the limit of detection within 50 days for all of the combinations tested. A 2-3 log die-off of Salmonella spp. occurred within three weeks. However, occasional detections continued throughout trial A. As a result, the probability of detection after 50 days fell from 1.0 to 0.1 and 0.02 in trials B and C, respectively, but remained at 0.44 in trial A. Listeria spp. was the most persistent in soil but was not detected on lettuce at commercial maturity. While this study was limited in scope, the results suggest that a 90 day withholding period between application of manure and harvest significantly reduces risk from enteric pathogens under Australian field conditions.
\end{abstract}

Keywords: E. coli; Salmonella; Listeria; food safety; lettuce; leafy vegetable; manure

\section{Introduction}

Animal manure has been used to improve agricultural soil fertility for over 7000 years [1]. Manures add nutrients and organic matter, increase soil bulk density, enhance structure and water holding capacity and increase biodiversity [2]. The beginnings of plant cultivation are intimately linked to animal herding, contributing to use of this technique across multiple continents and wide ranging climatic zones [1].

However, manures can contain human pathogens such as toxigenic E. coli, Salmonella spp., Listeria monocytogenes, Campylobacter spp., and Yersinia enterocolitica. It is critically important to prevent pre-harvest contamination with these pathogens, as postharvest sanitisers have limited efficacy against bacteria present on fresh vegetables, particularly leafy greens [3-5].

Untreated manures are therefore an important potential source of contamination of fresh vegetables. Pathogens in manure can contaminate vegetables grown in or close to 
the soil $[6,7]$. However, many human pathogenic bacteria are relatively poorly adapted to the soil environment. The die-off rates of human pathogens once added to soils has been widely studied. Reports of survival are extremely varied, ranging from only a few days to many months or even longer. For example, E. coli O157:H7 remained detectable for up to 217 days under cool conditions in Georgia, USA [8] but only 16 days under somewhat similar conditions in the UK [9]. A thorough review of die-off rates from different studies [10] notes that most studies are from temperate climates, with very few conducted in warm or tropical regions. The authors also observe that persistence times tend to be longer in laboratory than field based studies, a finding confirmed in a recent meta-analysis of 42 published papers [11]. This analysis also revealed that temperature was the most important factor affecting die-off rates, with population declines significantly faster when weather is warm or hot compared to cool conditions. Many other factors including moisture, UV intensity, soil type, manure source, incorporation method, aeration, presence of roots and endogenous microflora can also influence persistence of human pathogens in soil $[2,12-14]$ contributing to the observed variability.

The results of field studies are further complicated by widely varying initial inoculum loads (often $\log 5 \mathrm{CFU} / \mathrm{g}$ to $\log 8 \mathrm{CFU} / \mathrm{g}$ manure) and different definitions of "die-off". Many studies report survival of $E$. coli based on the limit of detection through direct plating. However, this may be 1.3, 10 or $100 \mathrm{CFU} / \mathrm{g}$ dry weight of soil [2,13-15]. Moreover, pathogens may still be detectable by enrichment even when populations have fallen to extreme low levels [16,17]. Die-off is usually exponential, but can also show initial increases or intermediate peaks depending on the environmental conditions [18-20]. A simpler approach may therefore be to record the time required for a percentage reduction in the population [12]. For example, Tran et al. [11] estimated the time required for a 1-log reduction in populations of E. coli and Salmonella spp. (D values), thereby allowing the effects of temperature, incorporation method and other environmental conditions to be compared between studies.

It is unclear how the population of enteric pathogens in soil relates to the probability of contamination of the produce grown in it. While $0.11 \mathrm{log}$ CFU/g dry weight of soil may be considered the threshold of E. coli population viability [2], the number of bacteria constituting an infective dose on food ranges from over one million for enteropathogenic E. coli [21] to approximately thirty [22] or as few as ten cells [23] for virulent strains of enterohemorrhagic E. coli such as O157:H7. Pathogens in manure-amended soil can colonise seedlings during germination [24], as well as transfer from the soil to leaves through water splash or dust [25]. E. coli can also be taken up by lettuce roots and transported into the leaves, a principle demonstrated using manure slurry containing $\log 8.1 \mathrm{CFU} / \mathrm{g}$ E. coli applied to mature plants [26]. A study by Islam et al. [8] found that parsley and lettuce were contaminated with $>10 \mathrm{CFU} / \mathrm{g}$ E. coli even when harvested 160 and 70 days, respectively, after amendment with manure containing $\log 7 \mathrm{CFU} / \mathrm{g}$ E. coli. The same group [27] reported that $E$. coli could still be detected on onions and carrots harvested 74 and 168 days after addition of inoculated manure or irrigation with contaminated water. Franz et al. [28] estimated that growing lettuce in soil amended with cattle manure (initial E. coli population of $2.49 \log$ CFU/g) would result in one externally contaminated head per 3.85 hectares, plus one internally contaminated head per 12.5 hectares.

Despite this, direct contamination from the soil appears to be less common than might be expected. Several studies have reported that human pathogens were rarely or not found on leafy vegetables (at least through direct plating) even when detectable populations were present in soil $[14,29,30]$. For soil to be considered "safe" to grow vegetables, it is therefore uncertain whether it needs to contain no detectable E. coli or $1 \mathrm{CFU} / \mathrm{g}, 10 \mathrm{CFU} / \mathrm{g}$ or even $100 \mathrm{CFU} / \mathrm{g}$ soil.

To reduce the risk of contamination, food safety programs generally mandate a time interval between application of untreated manures to soil and harvest. The current recommendation in the Australian Guidelines for Fresh Produce Safety [31] is for a withholding period of 90 days for high-risk products (grown close to or in the soil and may be eaten 
uncooked) and 45 days for all other products. These periods are shorter than those recommended in other guidelines. For example, in the USA, the National Organic Program mandates withholding periods of 120 and 90 days for high- and low-risk products, respectively [32], whereas GLOBALG.A.P. (Good Agricultural Practice) stipulates a minimum 60 day withholding period for all products regardless of risk [33].

In Australia, it has been suggested that the new Harmonised Australian Retailer Produce Scheme (HARPS) program adopt a 365 day withholding period, at least for high-risk products. The voluntary SaladGAP program (Australian Fresh Salad Producers Group) has already adopted this protocol [34], while both the UK Red Tractor Assurance Standard and California Leafy Greens Marketing Association mandate 12 months between application and planting for leafy greens $[35,36]$. Adopting such a lengthy withholding period would effectively preclude the application of untreated or semi-treated manures for many horticultural producers.

This project examined how rapidly populations of human pathogens in manure decline under conditions typical of those occurring during production of Australian leafy vegetable crops. Pathogen populations and rates of manure application were chosen based on the upper levels likely to occur under commercial conditions. Microbial tests were conducted by a commercial laboratory, replicating the data a grower would be able to access. Results are limited in scope, having been conducted over a single set of growing seasons (spring 2018, summer 2018-2019, autumn 2019), but may be considered in terms of their implications for current withholding periods.

\section{Materials and Methods}

Three complete trials were conducted over a seven month period, corresponding to spring (21 September to 21 November 2018); summer (11 December 2018 to 31 January 2019) and autumn (19 February to 9 April 2019), designated as trials A, B and C.

\subsection{Trial Site Preparation}

Forty $2 \mathrm{~m} \times 1 \mathrm{~m}$ boxes were installed at the University of Sydney Lansdowne farm $\left(34^{\circ} 01^{\prime} 16.1^{\prime \prime} \mathrm{S} 150^{\circ} 39^{\prime} 53.0^{\prime \prime} \mathrm{E}\right)$. Each box was dug $20 \mathrm{~cm}$ into the indigenous soil, then filled to $30 \mathrm{~cm}$ depth with either a sandy or clay loam soil, these being typical of soils in the region that are used to grow vegetables. Samples of untreated soil were also tested to confirm Listeria spp. and Salmonella spp. not detected in $25 \mathrm{~g}$ and E. coli $<10 \mathrm{CFU} / \mathrm{g}$.

Sentek soil moisture probes (Sentek EnviroSCAN, Stepney, Australia) were installed in eight boxes to record soil moisture at $10-50 \mathrm{~cm}$ depths. In addition, one web-based Wild Eye soil moisture probe (Wildeye Australia, Shenton Park, Australia) was located in each soil type. These could be interrogated remotely to check soil moisture levels and schedule irrigation. Temperature, rainfall and solar radiation data were accessed from the Bureau of Meteorology weather station at Camden Airport, located approximately $2.5 \mathrm{~km}$ from the trial site.

Each soil was tested to determine physico-chemical attributes and appropriate fertilizer program. The sandy soil had $\mathrm{pH} 6.2$, contained only $2 \%$ organic matter with $3 \mathrm{ppm}$ nitrate and had an electrical conductivity (EC) of 0.07 . The clay loam was much higher in organic matter at $8.1 \%$, with $114 \mathrm{ppm}$ nitrate, $\mathrm{pH} 5.3$ and EC 0.32 . The percentages of sand:silt:clay in sandy and clay loam soils were 27:3:5 and 27:27:36, respectively.

Based on a nutrient analysis of the soil, $50 \mathrm{~g}$ Nitrophoska Special (Incitec Pivot Fertilisers, $12 \% \mathrm{~N}, 5.2 \% \mathrm{P}, 14.1 \% \mathrm{~K}, 8 \% \mathrm{~S}, 3.2 \% \mathrm{Ca}, 1.2 \% \mathrm{Mg}$ ) and $120 \mathrm{~g}$ of Cal Nitrate (YaraLiva Tropicote $15.5 \% \mathrm{~N}+18.8 \% \mathrm{Ca}$ ) were worked into each box containing sandy soil before planting. The clay loam soil was fertilized with $60 \mathrm{~g}$ Super Mo (Paton Fertilizers Australia, $8.8 \% \mathrm{~N}, 11 \% \mathrm{~S}, 20 \% \mathrm{Ca}$ ) and $\mathrm{pH}$ was adjusted by addition of $400 \mathrm{~g} / \mathrm{box} \mathrm{CaCO}_{3}$ (trials $\mathrm{A}$ and $\mathrm{B}$ ). 


\subsection{Bacterial Cultures}

Previous testing of the manures indicated that they were unlikely to contain significant populations of E. coli, Salmonella spp. or L. monocytogenes. This was confirmed by testing each batch of manure on delivery. It was therefore necessary to inoculate manure with bacteria. Cultures of the non-pathogenic surrogates E. coli (derived from ATCC ${ }^{\circledR} 15597$ ), Listeria innocua (derived from ATCC ${ }^{\circledR}$ 51742) and Salmonella enterica subsp. salamae serovar sofia (S. sofia) were prepared by incubating "Kwik-Stiks" (lyophilised micro-organism pellets) for $24 \mathrm{~h}$ at $37^{\circ} \mathrm{C}$ in $5 \mathrm{ml}$ of tryptic soy broth. The resulting solutions were estimated to contain approximately $\log 9 \mathrm{CFU} / \mathrm{mL}$ populations of the relevant bacteria.

In Australia, Salmonella spp. is more commonly found in fresh poultry litter $(71 \%$ of samples) [37] than dairy cow manure (23\% of samples) [38], so this bacteria was added to the poultry litter only. In contrast, whereas L. innocua is rarely detected in poultry litter [37], it is frequently found in cow manure (approximately one-third of feedlot cattle samples) [39], making it appropriate to add this bacteria to the dairy cow manure.

\subsection{Manure Inoculation and Incorporation}

Raw, uncomposted poultry litter and dairy cow manure were sourced from a nearby composting facility. The 20 boxes/soil type were randomly allocated to five treatments:

1. Unamended control;

2. Poultry litter;

3. Dairy cow manure;

4. Poultry litter $+\log 5.0 \mathrm{CFU} / \mathrm{g}$ E. coli $+\log 3.4 \mathrm{CFU} / \mathrm{g}$ S. sofia;

5. Dairy cow manure $+\log 5.0 \mathrm{CFU} / \mathrm{g}$ E. coli $+\log 3.4 \mathrm{CFU} / \mathrm{g}$ L. innocua.

Each batch of manure for treatments 4 and 5 was inoculated individually from the original solutions. The inoculants were diluted in $2 \mathrm{~L}$ reverse osmosis $(\mathrm{RO})$ filtered water before mixing with the sample of manure.

Samples of $4 \mathrm{~kg}$ manure were incorporated into the top 5-8 $\mathrm{cm}$ of the soil in each box by systematic distribution with a three-pronged rake. This application rate is equivalent to $20 \mathrm{t} / \mathrm{ha}$. Although somewhat higher than the normal commercial application rate of 5-10 t/ha, this represents a "worst case" scenario.

In trial C, S. sofia added to poultry litter could not be detected in 7 of 8 soil samples taken immediately after incorporation of the inoculated manure. The bacteria were reinoculated by preparing the culture and diluents as previously, then making up to $5 \mathrm{~L}$ using additional $\mathrm{RO}$ water, ensuring it could be evenly distributed. This was watered across the boxes and lightly raked to incorporate before the lettuces were planted (Table 1).

Table 1. Trial start, lettuce planting and sampling dates.

\begin{tabular}{cccccc}
\hline \multirow{2}{*}{ Trial } & $\begin{array}{c}\text { Manure } \\
\text { Added }\end{array}$ & $\begin{array}{c}\text { Lettuce } \\
\text { Planted }\end{array}$ & \multicolumn{2}{c}{ Testing (Days from Start) } & \multirow{2}{*}{ Notes } \\
\cline { 4 - 5 } & & Soil & Lettuce & \\
\hline A & $21 / 9 / 18$ & $28 / 9 / 18$ & $\begin{array}{c}0,7,12,19,28,35, \\
42,50\end{array}$ & $42 *$ & \\
\hline B & $11 / 12 / 18$ & $17 / 12 / 18$ & $0,6,16,27,38,49$ & $27 ; 38 ; 49 *$ & \\
\hline C & $19 / 2 / 19$ & $26 / 2 / 19$ & $0,7,14,30,37,50$ & $37 ; 50 *$ & $\begin{array}{c}\text { Boxes with poultry } \\
\text { litter re-inoculated } \\
\text { at } 6 \text { days }\end{array}$ \\
\hline
\end{tabular}

${ }^{*}$ Lettuce harvested.

\subsection{Plant Materials}

Cos lettuce seedlings (Latuca sativa cv. Maximus) at the four-leaf maturity stage were planted at $20 \times 30 \mathrm{~cm}$ intervals six days after manure was added to the boxes. This reflects commercial practice, whereby beds are commonly prepared 3-7 days before planting. Plant density was designed to be similar to that in a normal commercial bed. Lettuce were 
watered using overhead irrigation with tank water sourced from the Hawkesbury river. The water was tested periodically to verify it contained $<1 \mathrm{CFU} / 100 \mathrm{~mL}$ E. coli.

A final assessment of yield was conducted once the lettuce reached commercial maturity. Six lettuce were randomly harvested at the base from each box, the outer leaves stripped and individual weight recorded.

\subsection{Sampling}

At the start of each trial, samples were taken of the inoculums, manures $(>100 \mathrm{~g} \times 3$ per type) and inoculated manures $(>100 \mathrm{~g} \times 4$ per type). Soil samples were taken from each box initially and after addition of the manures. Subsamples from the top $5-8 \mathrm{~cm}$ were aggregated from three randomly selected points in each box. The soil was resampled when the lettuce was planted six days later. Thereafter, soil samples were taken from all 40 boxes every 7-10 days for enumeration of E. coli. Soil samples were initially also tested for Salmonella spp. and Listeria spp. Testing was discontinued once each group of four boxes/treatment returned at least two "not detected" results.

Lettuce were tested for E. coli (CFU/g) as well as presence/absence of Salmonella spp. and Listeria spp. One lettuce from each of the 40 beds was sampled at harvest, as well as at intermediate points during trials B and C (Table 1). Lettuce heads were cut at ground level and tested with the dirty outer leaves still attached. While this is not commercial practice, it represents a "worst case" scenario that could allow cross contamination of harvested product.

\subsection{Microbial Testing}

All microbial testing was conducted by Symbio laboratories, Lane Cove. This laboratory is NATA (National Association of Testing Authorities) accredited to conduct these tests. The same testing procedures were used as would occur for commercial products:

\subsubsection{E. coli}

Enumeration was by petrifilm (M8.8, reference method AOAC 991.14). Samples of plant or soil material were roughly homogenised, then $10 \mathrm{~g}$ added to $90 \mathrm{~mL}$ sterile water and processed using a stomacher. After $2 \mathrm{~min}, 1 \mathrm{ml}$ of the diluted sample was inoculated onto selective petrifilm media (modified violet-red bile media containing 2,3,5-triphenyltetrazolium chloride and glucuronidase indicator). These were incubated at $35^{\circ} \mathrm{C}$ for $48 \mathrm{~h}$, then plates were examined for $E$. coli colonies. The colonies are typically surrounded by blue precipitate, with associated bubbles formed by fermentation of lactose. Results were converted to CFU/g with a limit of detection of $10 \mathrm{CFU} / \mathrm{g}$.

As frequently occurs with microbial testing, the data were extremely variable. The data were normalized by conversion to logs, with calculations made on the log values. Where E. coli was below the level of detection $(<10 \mathrm{CFU} / \mathrm{g})$, a conservative value of "9" was substituted $(\log 0.98)$ to allow graphical representation of the data.

\subsubsection{Salmonella spp.}

Detection was by VIDAS (M16.4, AOAC RI approved protocol no. 071101). A $25 \mathrm{~g}$ subsample of soil/plant tissue was enriched in buffered peptone water (BPW) and antibiotic supplements by incubating at $42{ }^{\circ} \mathrm{C}$ for 18 to $24 \mathrm{~h}$. A portion of the sample was then heated and run on the VIDAS instrument according to the manufacturer's instructions. This returns a result of not detected or presumptive positive.

Positive results from the VIDAS test were then confirmed by MALDI-ToF AOAC-OMA 2017.09 and Salmonella serology AS5013.10. A single well isolated colony is transferred to the MALDI target plate and the extended direct transfer method is applied. MALDI-ToF-MS measurement is then performed on the MALDI Biotyper and bacterial identification provided by the report. Salmonella suspect isolates are purified and tested for presence of somatic and flagella antigen. 
If Salmonella was detected, the population was estimated by the most probable number (MPN) method. A 3-tube technique was used with BPW; a $10 \mathrm{~mL}$ sample of broth was taken directly from each bag and serial dilutions used to prepare triplicate $10 \mathrm{~mL}$ tubes containing $0.1,0.01$ or $0.001 \mathrm{~mL}$ of the original inoculant. All tubes were then incubated at $37^{\circ} \mathrm{C}$ for 18 to $24 \mathrm{~h}$. Cultures from the tubes were streaked onto Salmonella spp. selective media (xylose lysine deoxylate agar) to determine growth. Well isolated colonies were selected and transferred to the MALDI target plate. MALDI-ToF-MS measurement was then performed on the MALDI Biotyper, the report confirming identification of the bacteria. Other, less well isolated colonies that were suspected of being Salmonella spp. were purified and tested for presence of somatic and flagella antigen. The approximate population could then be estimated from the number of positive results at each dilution rate.

As with E. coli, detections of Salmonella spp. and estimates of population (MPN), were extremely variable. To normalize the data, data were converted to logs, with calculations made on the log values. In order to graph the data, a number of assumptions had to be made with test data:

- Where Salmonella was detected, but the population was recorded as " $<3$ ", a value of "2" $(\log 0.3 \mathrm{CFU} / \mathrm{g})$ was substituted.

- Where Salmonella was not detected by enrichment, a value of "log 0 CFU/g" was substituted.

- As the maximum calculable value with MPN was ">1100", a value of "1200" $(\log 3.1 \mathrm{CFU} / \mathrm{g})$ was substituted.

\subsubsection{Listeria spp.}

Detection was by VIDAS (M13.4). A $25 \mathrm{~g}$ subsample of soil/plant tissue was enriched in buffered peptone water and antibiotic supplements by incubating at $42{ }^{\circ} \mathrm{C}$ for between 18 to $24 \mathrm{~h}$. A portion of the sample was then heated and run on the VIDAS instrument. This returns a result of not detected or presumptive positive. Positive results from the VIDAS test were confirmed by MALDI-ToF and Listeria serology AFNOR Bio-12/33-05/12.

\subsection{Statistical Analysis}

All population data were converted to CFU/g dry weight of soil. Data were normalized by conversion to logs, with calculations made on the log values. Where E. coli was below the level of detection (<10 CFU/g), a conservative value of "9" was substituted ( $\log 0.98)$ to allow graphical representation of the data. In the case of Salmonella spp., the maximum MPN result of ">1100 MPN/g" was substituted with "1200 MPN/g" while a result of detected, "<3 MPN/g" was substituted with "2 MPN/g".

\subsubsection{E. coli Data Modelling}

The E. coli data were modelled as count data (CFU) using a Poisson regression model with fixed factors for manure treatment, season and soil type. Time was treated as a fixed factor at six discrete timepoints. Univariate model parameters and AIC values were compared to those of larger (nested) models to check for robustness and model fit. The GENLINMIXED procedure in SPSS was used with Satterthwaite approximation and robust estimation of the parameter estimate covariance matrix. Residual plots were also investigated for major model violations such as outliers, variance mis-specification and unexplained structure.

Analyses were carried out using SPSS (IBM Corp. Released 2019. IBM SPSS Statistics for Windows, Version 26.0. Armonk, NY: IBM Corp).

\subsubsection{Salmonella spp. Data Modelling}

The Salmonella data were modelled as binary data (detected or not detected) using a logistic regression model. Explanatory variables included season and time for the 'poultry + inoc' treatment only. Nested models were checked for model fit and robustness. The LOGISTIC REGRESSION procedure in SPSS was used to fit all models. 
Analyses were carried out using SPSS (IBM Corp. Released 2019. IBM SPSS Statistics for Windows, Version 26.0. Armonk, NY: IBM Corp).

\section{Results}

\subsection{Initial Populations of Human Pathogens in Manures}

Initial testing of the manures used in all three trials for E. coli, Listeria spp. and Salmonella spp. was negative, with the exception of a single positive result of $E$. coli $\log 3.3 \mathrm{CFU} / \mathrm{g}$ in trial B (Table 2).

Table 2. Moisture content and microbial populations $(n=3)$ in manures before and after inoculation with human pathogens. $\mathrm{D} / \mathrm{ND}$ indicates detected/not detected.

\begin{tabular}{|c|c|c|c|c|c|}
\hline Treatment & Trial & $\begin{array}{c}\text { Moisture } \\
\text { Content (\%) }\end{array}$ & $\begin{array}{c}\text { E. coli } \\
(\log \text { CFU/g) }\end{array}$ & $\begin{array}{l}\text { Salmonella spp. } \\
\text { (Log MPN/g) }\end{array}$ & $\begin{array}{l}\text { Listeria spp. } \\
\text { (D/ND) }\end{array}$ \\
\hline \multirow{3}{*}{ Poultry litter } & A & 43 & $<1$ & ND & ND \\
\hline & B & 30 & $<1$ to 3.3 & ND & ND \\
\hline & $\mathrm{C}$ & 28 & $<1$ & ND & ND \\
\hline \multirow{3}{*}{$\begin{array}{l}\text { Poultry litter }+ \\
\text { E. coli }+ \text { S. sofia }\end{array}$} & A & 43 & $<1$ & $>3.0$ & ND \\
\hline & B & 30 & 4.0 to 4.5 & 1.5 to 3.0 & ND \\
\hline & $\mathrm{C}$ & 28 & 4.2 to 4.4 & 1.4 to 3.0 & ND \\
\hline \multirow{3}{*}{ Cow manure } & A & 28 & $<1$ & ND & ND \\
\hline & B & 40 & $<1$ & ND & ND \\
\hline & $\mathrm{C}$ & 36 & $<1$ & ND & ND \\
\hline \multirow{3}{*}{$\begin{array}{c}\text { Cow manure }+ \\
\text { E. coli }+ \\
\text { L. innocua }\end{array}$} & A & 28 & 2.8 to 3.0 & ND & Detected \\
\hline & B & 40 & 4.7 to 5.2 & ND & Detected \\
\hline & $\mathrm{C}$ & 36 & 5.0 to 5.1 & ND & Detected \\
\hline
\end{tabular}

The populations of microbes in the inoculated manures varied, even though the same procedures were followed each time.

\subsection{Climate and Soil Moisture}

Soil moisture was relatively consistent across all three trials for the initial 30 days of crop growth. Average soil moisture remained relatively constant through to harvest during trial C, but fell as plants approached harvest during trials A and B (Figure 1a). Temperatures also rose as the lettuce developed in trials A and B (Figure 1b). As a result, irrigation was insufficient to replace moisture lost due to evaporation as well as increased demands by the rapidly growing lettuce. Despite this variability in soil moisture, commercial quality lettuce was produced in all three trials.

Daily temperatures fluctuated considerably in all trials. Maximum temperatures during the first three weeks of each trial were relatively mild for trial $\mathrm{A}\left(20-25^{\circ} \mathrm{C}\right)$, whereas they were very hot $\left(30-40{ }^{\circ} \mathrm{C}\right)$ during trial $\mathrm{B}$ and remained hot $\left(25-35^{\circ} \mathrm{C}\right)$ during trial C. Median temperatures increased during trials $\mathrm{A}$ and $\mathrm{B}$ but decreased from the initially high maximum temperatures during trial $\mathrm{C}$ (Figure $1 \mathrm{~b}$ ). As temperatures declined, so did the intensity of solar radiation. The total number of days with $>20 \mathrm{MJ} \cdot \mathrm{m}^{2}$ solar radiation fell from 27 and 32 for the trials $A$ and B, respectively, to only 9 during trial $C$ (Figure 1c). In summary, trials $A$ and $B$ tended to have high temperatures, strong solar radiation and dry conditions leading up to harvest compared to the milder conditions experienced during trial C. 


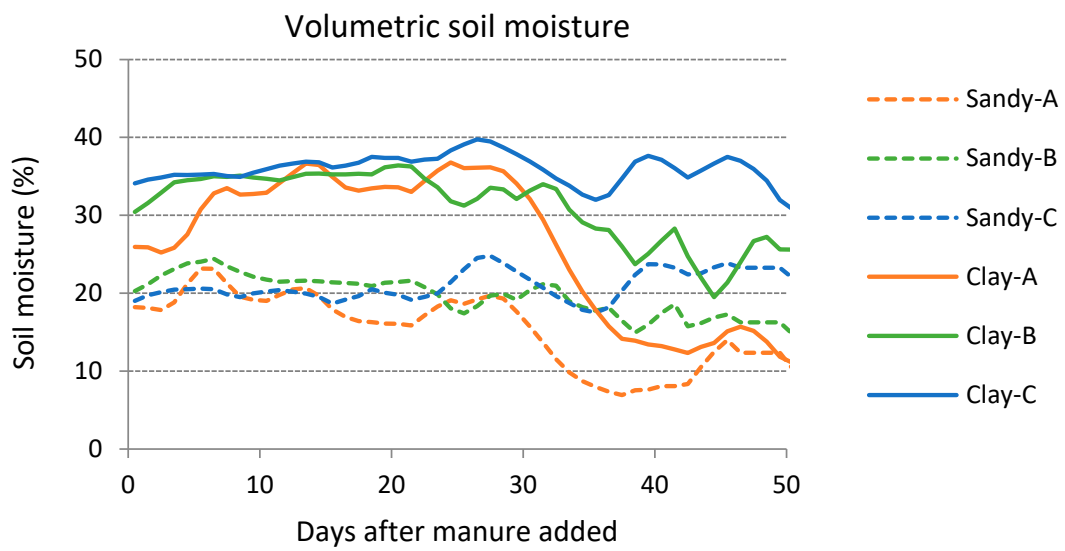

(a)

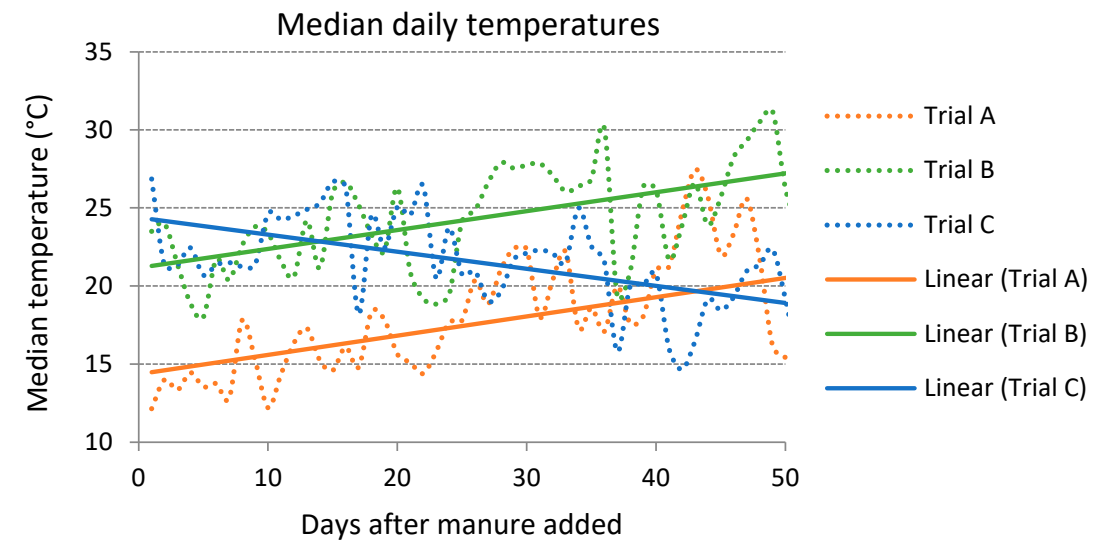

(b)

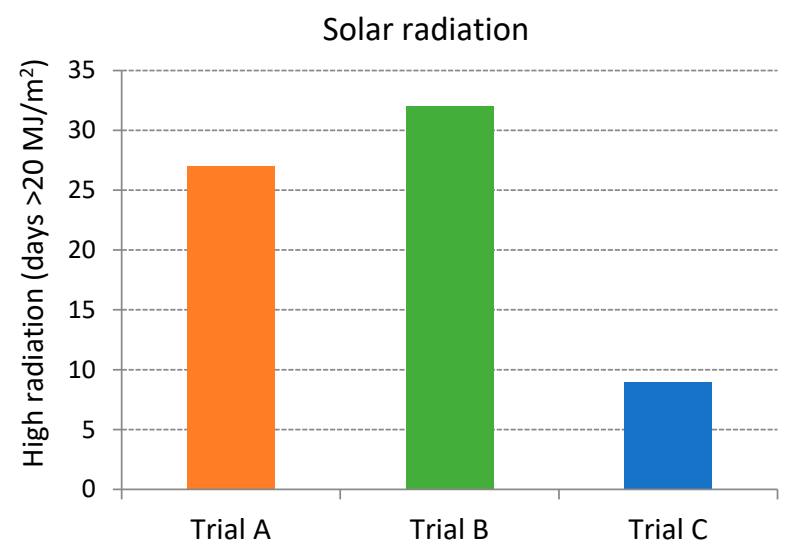

(c)

Figure 1. (a) Average soil moisture in sandy (dashed lines) and clay loam (solid lines) soils for trials $\mathrm{A}, \mathrm{B}$ and $\mathrm{C}$. Values are running means from $24 \mathrm{~h}$ data. (b) Median daily temperatures, with linear trend lines plotted. (c) Total days during each trial with $>20 \mathrm{MJ} / \mathrm{m}^{2}$ solar radiation.

\subsection{Survival of E. coli in Manure-Amended Soils}

As microbial test data are extremely variable, all of the data are presented in Figures 2 and 3, thereby indicating the full range of populations recorded. 


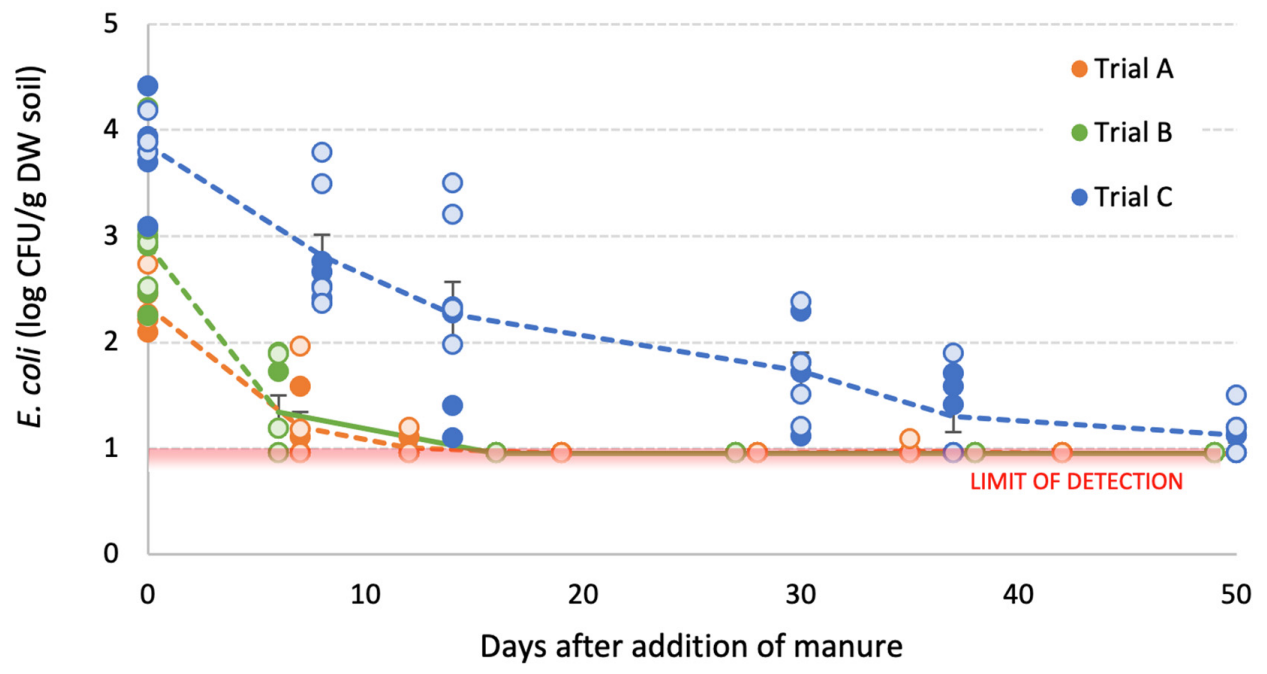

Figure 2. Populations of E. coli in sandy $(\bullet)$ and clay loam $(\mathbf{O})$ soil amended with cow manure inoculated with E. coli and L. innocua. Each point represents a test result (4 points/sampling time/soil type/trial) and is expressed per gram dry weight ( $\mathrm{g} D$ ) of soil. Dashed lines indicate the mean for each dataset; bars indicate the standard error of mean values.

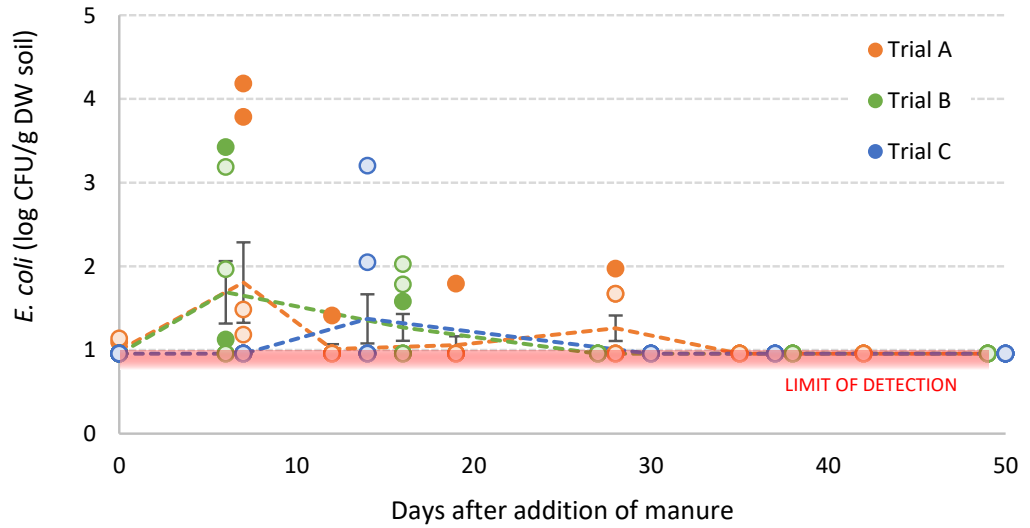

(a)

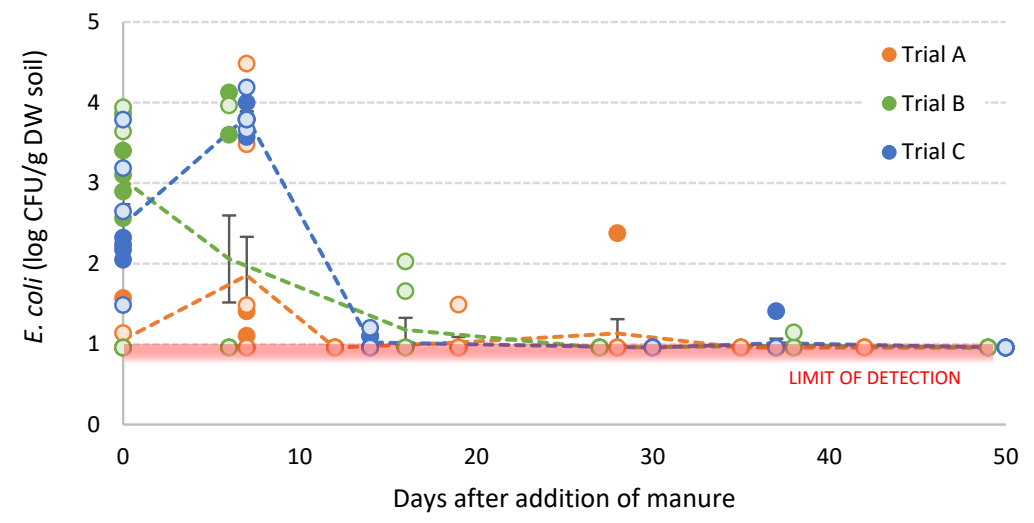

(b)

Figure 3. Populations of E. coli in sandy $(\bullet)$ and clay loam (0) soil amended with (a) poultry litter or (b) poultry litter inoculated with E. coli and $S$. sofia. Each point represents a test result (4 points/sampling time/soil type/trial). Dashed lines indicate the mean for each dataset; bars indicate the standard error of mean values. 
There were significant differences between the trials and manure types, as well as changes over time. Differences between the soil types were not statistically significant (Table 3). Populations were highest and had the greatest variance within one week of application of manure to soil. They were also significantly higher in trial $\mathrm{C}$ than trials $\mathrm{A}$ and $\mathrm{B}$.

Table 3. Analysis of treatment effects on E. coli populations in manure-amended soil.

\begin{tabular}{ccccc}
\hline Source & $\mathbf{F}^{*}$ & $\mathbf{d f 1} \mathbf{~}^{* *}$ & $\mathbf{d f 2}{ }^{* *}$ & Significance \\
\hline Corrected model & 41.13 & 32 & 29 & 0.000 \\
Trial (season) & 5.685 & 2 & 6 & 0.045 \\
Soil type & 2.513 & 1 & 5 & 0.176 \\
Manure type & 157.973 & 4 & 104 & 0.000 \\
Time & 154.491 & 5 & 19 & 0.000 \\
Manure $\times$ time & 60.606 & 20 & 40 & 0.000 \\
\hline
\end{tabular}

${ }^{*} \mathrm{~F}=$ the test statistic; ${ }^{* *} \mathrm{df}=$ degrees of freedom.

\subsubsection{Inoculated Dairy Cow Manure}

E. coli was only detected in boxes amended with inoculated cow manure; no E. coli was detected in boxes with cow manure alone.

In trials A and B, E. coli populations fell to close to the level of detection within 10 days of addition to the soil. However, the results from autumn (C) provide an important exception. Even though the populations of E. coli in manure before application were consistent between the trials, populations measured shortly after the manure was incorporated into soil were $\log 1.0$ to 1.5 higher in trial C than trials A and B. Two of eight samples remained $>\log 2 \mathrm{CFU} / \mathrm{g}$ when measured 30 days after incorporation of the manure (Figure 2). It seems possible that more consistent soil moisture, lower solar radiation and falling temperatures increased persistence of $E$. coli in this environment.

\subsubsection{Poultry Litter}

Unlike the results for cow manure, E. coli was detected in boxes with both inoculated and non-inoculated poultry litter. However, high detections (>log $2 \mathrm{CFU} / \mathrm{g})$ were far more frequent in the inoculated material, resulting in higher average values. The highest populations were observed approximately one week after incorporation of manure into the soil in 4 of the 6 datasets. However, populations subsequently declined, with only occasional detections more than 20 days after addition of the manure in both inoculated and non-inoculated boxes (Figure 3).

\subsubsection{Generalised E. coli Population Model}

For the purposes of analysis, samples were grouped according to time from start, giving generalised times of (approximately) 7, 14, 30, 40 and 50 days. The model indicated that $E$. coli would be expected to be at or close to the limit of detection 50 days after manure was added to the soil for all of the combinations tested and across all seasons. This suggests that populations are forecast to decline by at least $\log 3(99.9 \%)$ over this time interval (Figure 4). 


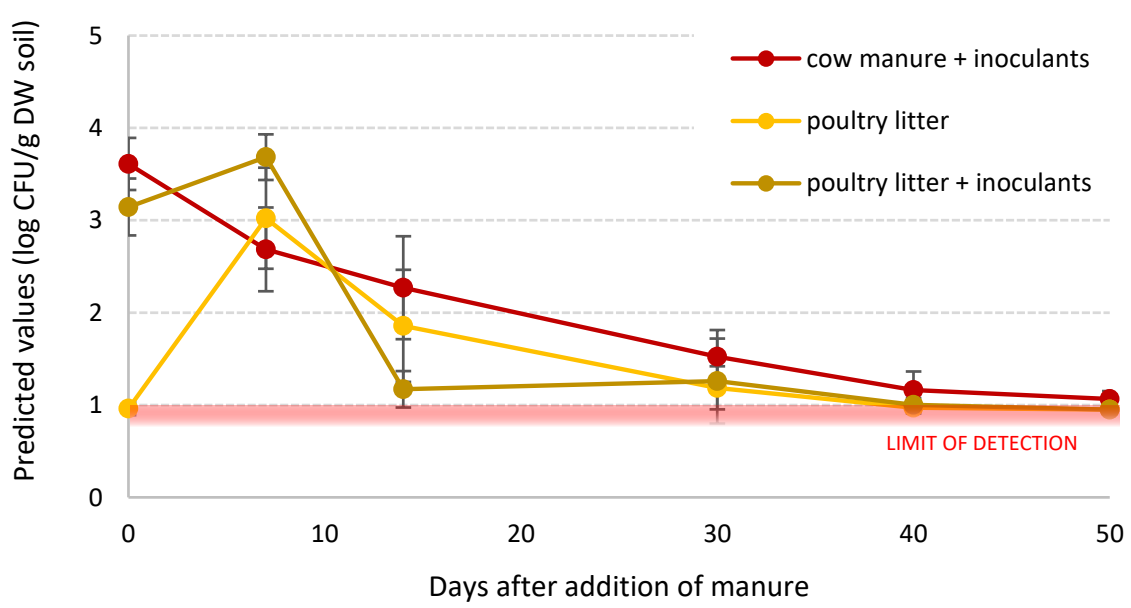

Figure 4. Predicted populations of E. coli in soil following amendment with cow manure inoculated with E. coli + L. innocua; poultry litter alone; or poultry litter inoculated with E. coli and S. sofia. Bars indicate the confidence interval of each predicted value. Note that there were no detections of $E$. coli in cow manure only.

\subsection{Survival of S. sofia in Poultry Litter Amended Soils}

Low populations of Salmonella spp. continued to be detected 50 days after application of contaminated poultry litter during trial A (spring), although most were at the limit of enumeration $(\log 0.48 \mathrm{MPN} / \mathrm{g})$. This trial also recorded the most consistently high populations immediately after addition of the manure to the boxes (Figure 5).

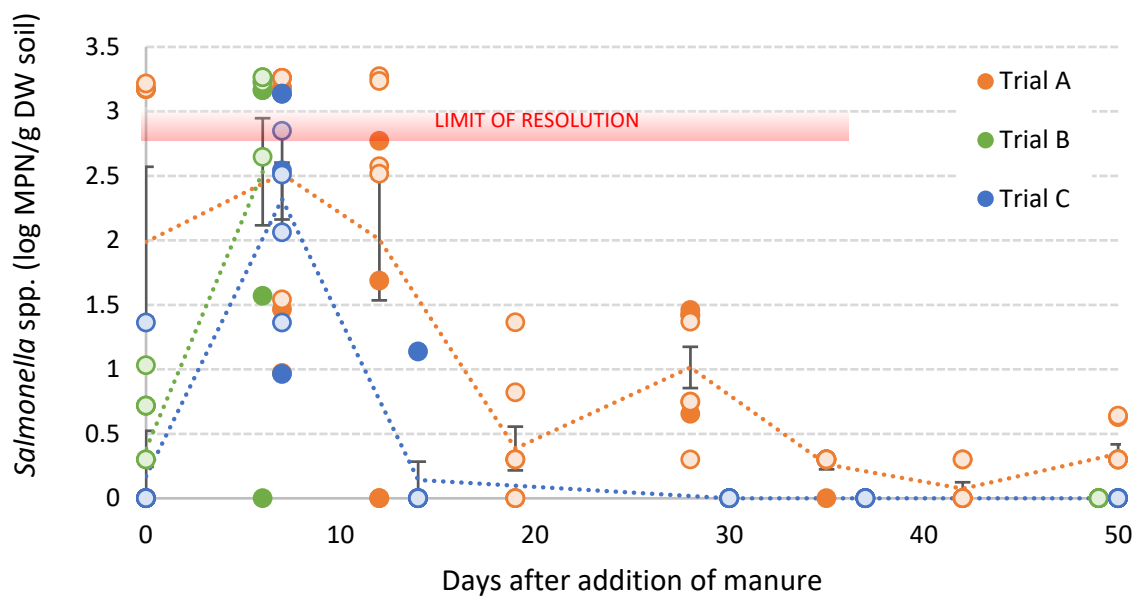

Figure 5. Populations of Salmonella spp. in sandy $(\bullet)$ and clay loam $(\mathbf{O})$ soil amended with poultry litter inoculated with $S$. sofia (b). Each point represents a test result (4 points/sampling time/soil type/trial). Dashed lines indicate the mean for each dataset; bars indicate the standard error of mean values.

There were no detections of Salmonella three weeks or more after manure addition during trials $B$ and $C$. In the case of trial $C$, this was despite re-inoculation with additional S. sofia 6 days after the initial contamination event.

Although the odds ratio of detection of Salmonella spp. in sandy soil was 0.757 times the odds of detecting it in clay loam soil, there was a large associated $95 \%$ confidence interval (lower $=0.393$; upper $=1.457)$ and the difference was not significant $(p=0.405)$.

Modelling of Salmonella data was based on presence/absence rather than population, due to the zero tolerance for this pathogen on harvested product. Logistic regression of the data indicated that there was a significant difference between seasons and over time.

Calculation of odds ratios indicated that the odds of detection of Salmonella spp. was 41.5 and 5.7 times more likely in trials A and B when compared to trial C. Detection was 
most likely one week after initial addition to the soil; after 50 days detection was 0.15 times as likely.

The probability of detection after 50 days was 0.1 and 0.02 in trials $B$ and $C$, respectively. However, after 50 days in spring (A), the probability of detection remained 0.44 , suggesting a nearly 50:50 chance of detecting Salmonella spp. in soil (using enrichment) after this time interval (Table 4).

Table 4. Predicted probability of detecting Salmonella spp. in soil amended with inoculated poultry litter.

\begin{tabular}{ccccccc}
\hline \multirow{2}{*}{ Trial } & \multicolumn{7}{c}{ Days after Addition of Manure } \\
\cline { 2 - 7 } & $\mathbf{0}$ & $\mathbf{7}$ & $\mathbf{1 4}$ & $\mathbf{3 0}$ & $\mathbf{4 0}$ & $\mathbf{5 0}$ \\
\hline A & 0.11 & 0.90 & 0.06 & 0.13 & 0.03 & 0.02 \\
B & 0.84 & 1.00 & 0.72 & 0.87 & 0.55 & 0.44 \\
C & 0.42 & 0.98 & - & - & - & 0.10 \\
\hline
\end{tabular}

\subsection{Survival of L. innocua in Dairy Cow Manure-Amended Soils}

Listeria spp. was only detected in boxes amended with inoculated cow manure. There was no difference in frequency of detection between the sandy and clay loam soil, so these data were combined. As Listeria spp. was not enumerated, results are presented as the proportion of the eight boxes/trial that were positive at each sampling time. While detections generally decreased over each trial period, it is evident that Listeria spp. persisted more than 50 days in both the spring and autumn trials (Figure 6).

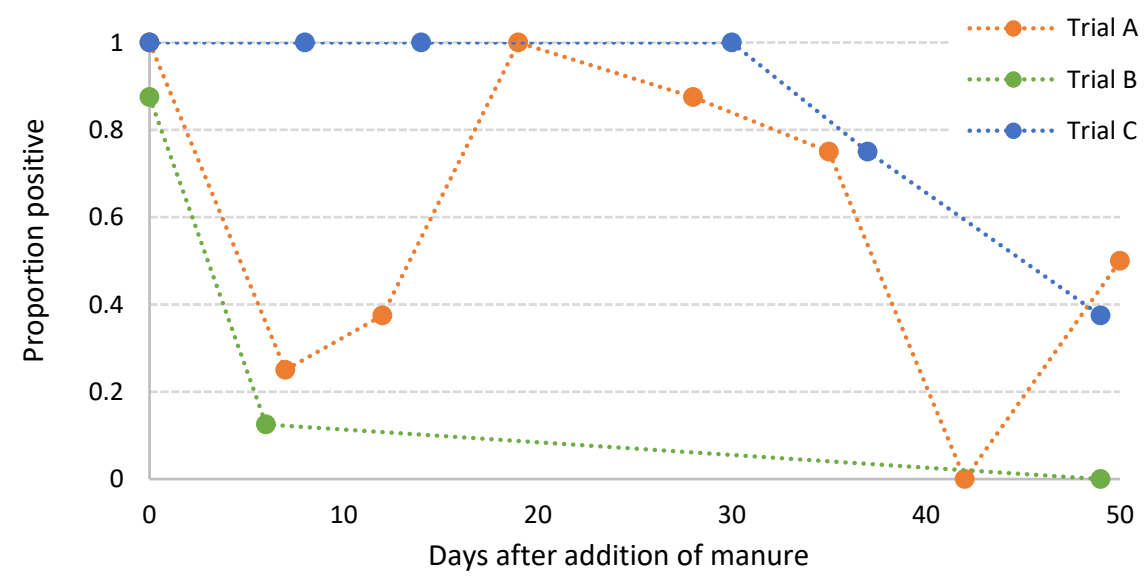

Figure 6. Proportion of samples positive for Listeria spp. in soil amended with dairy cow manure inoculated with L. innocua $(n=8)$.

\subsection{Pathogen Detection on Lettuce}

There were no detections of human pathogens on mature lettuce in trial A. There were three detections of E. coli on lettuce during trial B. However, the only detection at harvest was from an unamended bed. This detection was $>\log 4$ CFU /g, making it considerably higher than other detections. During trial C, there were two detections of Listeria spp. on immature lettuce, but no detections at harvest maturity. Salmonella spp. was not detected at any time (Table 5). 
Table 5. Detections of human pathogens on harvested lettuce, $n=40$ heads/sampling time.

\begin{tabular}{cccc}
\hline Trial & Days from Start & Detections & Treatment \\
\hline A & 42 & None & - \\
\hline & 27 & $1 \times E . \operatorname{coli} \log 2.4 \mathrm{CFU} / \mathrm{g}^{-1}$ & Poultry litter \\
B & 38 & $1 \times E . \operatorname{coli} \log 2.2 \mathrm{CFU} / \mathrm{g}^{-1}$ & Inoculated cow manure \\
& 49 & $1 \times E . \operatorname{coli} \log 4.6 \mathrm{CFU} / \mathrm{g}^{-1}$ & Unamended control \\
\hline \multirow{2}{*}{$\mathrm{C}$} & 37 & $2 \times$ Listeria spp. detected & Inoculated cow manure \\
& 50 & None & - \\
\hline
\end{tabular}

\subsection{Lettuce Yield and Quality}

At commercial maturity, lettuce grown in sand with poultry manure were visually larger than those with cattle or no manure. Average head weights in sandy soil were significantly greater in boxes amended with poultry litter for all trials. Cattle manure had no consistent effect on head weight in clay loam or sandy soil (Table 6)

Table 6. Average head weight $(\mathrm{g})$ of lettuce grown in clay loam or sandy soil, with the addition of poultry litter $(n=48)$, dairy cow manure $(n=48)$ or no amendment $(n=24)$. Letters indicate means that are significantly different within rows $(p<0.05)$; ns = not significantly different.

\begin{tabular}{|c|c|c|c|c|c|c|c|c|c|c|c|c|}
\hline \multirow{3}{*}{$\begin{array}{c}\text { Trial } \\
\text { A }\end{array}$} & \multicolumn{6}{|c|}{ Clay Loam } & \multicolumn{6}{|c|}{ Sand } \\
\hline & \multicolumn{2}{|c|}{ Poultry } & \multicolumn{2}{|c|}{ Cow } & \multicolumn{2}{|c|}{ Unamended } & \multicolumn{2}{|c|}{ Poultry } & \multicolumn{2}{|c|}{ Cow } & \multicolumn{2}{|c|}{ Unamended } \\
\hline & 464.4 & $\mathrm{~b}$ & 479.0 & $\mathrm{~b}$ & 534.5 & $\mathrm{a}$ & 510.8 & $\mathrm{a}$ & 438.3 & $b$ & 388.8 & c \\
\hline B & 629.4 & $\mathrm{a}$ & 613.8 & $\mathrm{a}$ & 620.8 & $\mathrm{a}$ & 664.6 & a & 594.8 & $b$ & 566.7 & $\mathrm{~b}$ \\
\hline $\mathrm{C}$ & 532.0 & ns & 564.8 & ns & 529.2 & ns & 567.6 & a & 298.4 & $b$ & 354.0 & $\mathrm{~b}$ \\
\hline
\end{tabular}

\section{Discussion}

Die-off rates of human pathogens in manure-amended soils has been widely researched. Alegbeleye et al. [6] recently reviewed nearly 70 research papers investigating die-off rates of E. coli, Salmonella spp. or L. monocytogenes, many of which involved large and complex trials. For example, Sharma et al. [2] conducted 12 field trials examining survival of $E$. coli in soils amended with four types of manure at three sites over a four year period, with differing inoculum levels, site management and incorporation methods. This study found wide variations at different sites and seasons, with persistence affected by temperature, moisture, manure type and site management. The number of days until E. coli fell below $\log 0.11 \mathrm{MPN} / \mathrm{g}$ ranged from only 5 days to more than 219 days. In another recent study [40], the time taken for a $99.9 \%(\log 3)$ reduction in the E. coli or Salmonella spp. population ranged from 2 days to 120 days, depending on moisture levels and temperature.

This variability is typical of trial results examining die-off rates of human pathogens in manure-amended soil. It makes it difficult, if not impossible, to mandate an appropriate "one-size-fits-all" withholding period between manure application and harvest for all environments and situations. However, "it depends ... " is not useful guidance for farmers wanting to ensure their products are safe to eat. As a result, and despite this abundance of data, a recent survey of producers in the USA concluded that there remains an urgent need for science-based information on appropriate withholding times between application of manure and harvest [32].

In our trials, soil type (clay loam vs. sandy soil) had no significant effect on pathogen persistence. However, other studies have found increased [24,41-43], decreased [12,44] or approximately similar [20,29] persistence of microbes in clay compared to sandy soils. Soil type (and presence of plant roots) may increase survival of human pathogens through improved nutrient availability [13,14], reduced diversity of indigenous microbes [45] or improved moisture retention [44].

It was noted that the characteristics of the raw poultry litter appeared to initially reduce survival of inoculated E. coli and/or S. sofia. This was particularly an issue at the start 
of trial C, where 7 of 8 boxes returned negative results for Salmonella spp. when sampled immediately after addition of the inoculated manure. The boxes were re-inoculated 6 days later, which successfully increased Salmonella spp. detections and allowed enumeration of the population. In general, the E. coli populations recorded in inoculated poultry litter (Table 2) and immediately after addition of poultry litter to soil (Figure 3b) were lower and more variable than those observed in inoculated cattle manure (Table 2 and Figure 2). This suggests that variability was not due to uneven mixing or methodology, but factors within the poultry litter. It seems possible that low $\mathrm{pH}$, ammonia or even antibiotic residues in the poultry litter may have had antimicrobial effects. This unknown factor also likely contributed to the reductions in E. coli and Salmonella spp. populations that occurred within a few days or weeks after poultry litter was added to the soil.

While the effects of soil and manure type are variable, there is no doubt that temperature is a key predictor of decline. Both E. coli and Salmonella spp. consistently die-off more quickly at higher temperatures [11]. High daily temperatures occurred during all of the current trials. For example, maximum daily temperatures exceeded $30^{\circ} \mathrm{C}$ on 11,36 and 15 occasions during trials A, B and C, respectively. During trial B there were three days where temperatures rose over $40^{\circ} \mathrm{C}$. These high temperatures likely contributed to the relatively rapid declines in E. coli and Salmonella spp. populations that occurred in these trials compared to, for example, trials commenced during autumn in Maryland, USA [8,27].

The time taken for a $1 \mathrm{log}$ reduction in E. coli ranged from 2.5 to 8.8 days, averaging 5.7 days across the three trials and two soil types. The same reduction in Salmonella spp. required an average 4.4 days. This is slightly shorter, but consistent with, the meta-analysis conducted by Tran et al. [11], which calculated that the median time needed for 1 log reductions in E. coli and Salmonella spp. were 7.6 days and 5.7 days, respectively, at medium temperatures $\left(10\right.$ to $\left.20^{\circ} \mathrm{C}\right)$.

Estimating the time taken for a $1 \log$ reduction in population assumes a linear rate of decrease. However, initial rapid die-off is frequently followed by an increasingly slow rate of decline, albeit with occasional higher detections. The time until human pathogens fall to a particular study's "limit of detection" is therefore highly dependent on both the initial contamination rate and the methods used for detection. For example, the time taken for E. coli and Salmonella Typhimurium to reach the direct detection limit was 24 and 30 days, respectively, when inoculated at $\log 4 \mathrm{CFU} / \mathrm{g}$, but increased to 85 and 91 days, respectively, when the soil was inoculated with $\log 7$ CFU/g [14].

In these trials we used the relatively low inoculation rates of $\log 5 \mathrm{CFU} / \mathrm{g}$ E. coli and $\log 3.4 \mathrm{CFU} / \mathrm{g}$ S. sofia/L. innocua in manure. Many studies have used higher rates, inoculating manure with up to $\log 8 \mathrm{CFU} / \mathrm{g}$ of E. coli or Salmonella spp., and $\log 6 \mathrm{CFU} / \mathrm{g}$ L. monocytogenes [6]. The lower rates were used in order to reproduce median levels found in Australian manure samples $[37,39,46,47]$ thereby attempting to provide a realistic scenario of die-off rates in a field production situation. As a result, maximum E. coli populations in manure-amended soil rarely exceeded $\log 4 \mathrm{CFU} / \mathrm{g}$ and declined to the limit of detection $(10 \mathrm{CFU} / \mathrm{g})$ within 50 days of addition to soil. Populations of Salmonella spp. generally showed a similar decline to E. coli, falling close to or below the limit of enumeration $(3 \mathrm{MPN} / \mathrm{g}$ ) within 50 days of addition to soil in all three trials.

These results are consistent with the conclusions of Çekiç et al. [48] who found that, although E. coli was occasionally detectable for up to 280 days, populations fell below $0.2 \mathrm{CFU} / \mathrm{g}$ soil within 56 days of application. Similarly, Franz et al. [30] found E. coli populations fell from $\log 1.5$ to 2.5 to the limit of detection within 56 days in soil amended with cow manure, Salmonella spp. declining from $\log 3.5$ to 4.5 to $\log 1$ or less over the same time period. Ingham et al. [24] found that E. coli populations declined by log 2.4 to 2.5 within 45 days of application, although the bacteria was still regularly detected by enrichment for at least 120 days.

Enrichment theoretically allows detection of as little as a single bacterium in a sample. Our data indicated that there was an increased probability of detecting human pathogens 50 days after addition to soil when the test involved enrichment. This was most strongly 
the case for Listeria spp.; there was a 38-50\% probability of detecting Listeria spp. after 50 days in trials $\mathrm{A}$ and $\mathrm{C}$, although it was not detected at the end of the summer trial (B). This is perhaps unsurprising; the inoculated bacteria L. innocua is very closely related to the human pathogen L. monocytogenes [49] and, as a natural soil-dwelling organism, has previously been shown to be more persistent in soil than E. coli [50]. Persistence of L. monocytogenes is strongly affected by soil $\mathrm{pH}$, moisture and texture as well as microbial activity. Populations may decline to the limit of detection within 8 to 10 days at $25^{\circ} \mathrm{C}$ [49], or persist for more than 84 days in soils with high $\mathrm{pH}$ and clay content [51]. The results in these trials are consistent with previous publications in that Listeria spp. is more persistent when temperatures are mild and soil remains moist [51-53].

However, it is unclear how positive detections in soil relate to contamination risk for leafy vegetables, especially where the population cannot be enumerated. In these trials, Listeria spp. was detected on two immature lettuce, but was not found at harvest maturity, even though the bacteria remained detectable in soil. Salmonella spp. was not detected on any harvested lettuce and, of the three detections of $E$. coli, the highest was from soil which contained no manure. Moreover, there were significant production benefits from manure application; lettuce grown in sandy soil were significantly larger $(p<0.05)$ when soil was amended with poultry litter. Understanding persistence in soil allows such benefits to be weighed against the potential risks from using manures.

\section{Conclusions}

Three trials were conducted examining persistence of E. coli, Salmonella spp. and Listeria spp. in manure-amended soil. The trials used inoculation rates, cultural practices and testing methods that were consistent with what could occur on a commercial Australian vegetable farm.

E. coli fell close to or below the limit of detection within 50 days of addition of inoculated manure to soil regardless of soil characteristics, manure type and season. Populations of Salmonella spp. showed a similar decline, falling close to or below the level of enumeration within 50 days, although the bacteria could still be detected by enrichment in trial A. Listeria spp. could also be detected in approximately $30 \%$ of all samples (using enrichment) 50 days after addition to the soil.

These trials were conducted in a single location over a relatively short time period, which limits the inferences that can be drawn from these results. Nevertheless, the rapid die-off rates of E. coli and Salmonella spp. populations in soil, combined with low contamination rates on harvested lettuce, suggest that the current recommended withholding period of 90 days between manure application and harvest significantly reduces the risk of contamination of harvested product.

Author Contributions: Conceptualization, J.E. and M.B.; methodology, J.E., A.G. and M.B.; formal analysis, J.M.; resources, A.G.; data curation, J.E. and A.G.; writing-original draft preparation, J.E.; writing-review and editing, A.G., M.B. and G.R.; project administration, G.R.; funding acquisition, J.E. All authors have read and agreed to the published version of the manuscript.

Funding: This research was funded by Hort Innovation Australia Ltd. using the vegetable industry research and development levy and funds from the Australian Government (VG16042).

Data Availability Statement: Data is contained within the article and available on request from the corresponding author.

Conflicts of Interest: The authors declare no conflict of interest. 


\section{References}

1. Bogaard, A.; Fraser, R.; Heaton, T.H.E.; Wallace, M.; Vaiglova, P.; Charles, M.; Jones, G.; Evershed, R.P.; Styring, A.K.; Andersen, N.H.; et al. Crop manuring and intensive land management by Europe's first farmers. Proc. Natl. Acad. Sci. USA 2013, 110, 12589-12594. [CrossRef] [PubMed]

2. Sharma, M.; Millner, P.D.; Hashem, F.; Vinyard, B.T.; East, C.; Handy, E.T.; White, K.; Stonebraker, R.; Cotton, C.P. Survival of Escherichia coli in Manure-Amended soils is Affected by Spatiotemporal, Agricultural, and Weather Factors. Appl. Environ. Microbiol. 2019, 85, e02392-18. [CrossRef] [PubMed]

3. Osaili, T.M.; Alaboudi, A.R.; Al-Quran, H.N.; Al-Nabulsi, A.A. Decontamination and survival of Enterobacteriaceae on shredded iceberg lettuce during storage. Food Microbiol. 2018, 73, 129-136. [CrossRef] [PubMed]

4. Shirron, N.; Kisluk, G.; Zelikovich, Y.; Eivin, I.; Shimoni, E.; Yaron, S. A comparative study assaying commonly used sanitizers for antimicrobial activity against indicator bacteria and a salmonella typhimurium strain on fresh produce. J. Food Prot. 2009, 72, 2413-2417. [CrossRef]

5. Prado-Silva, L.; Cadavez, V.; Gonzales-Barron, U.; Rezende, A.C.B.; Sant'Ana, A.S. Meta-analysis of the effects of sanitizing treatments on Salmonella, Escherichia coli O157:H7, and Listeria monocytogenes inactivation in fresh produce. Appl. Environ. Microbiol. 2015, 81, 8008-8021. [CrossRef]

6. Alegbeleye, O.O.; Singleton, I.; Sant'Ana, A.S. Sources and contamination routes of microbial pathogens to fresh produce during field cultivation: A review. Food Microbiol. 2018, 73, 177-208. [CrossRef]

7. Hirneisen, K.A.; Sharma, M.; Kniel, K.E. Human enteric pathogen internalization by root uptake into food crops. Foodborne Pathog. Dis. 2012, 9, 396-405. [CrossRef]

8. Islam, M.; Doyle, M.P.; Phatak, S.C.; Millner, P.; Jiang, X. Persistence of Enterohemorrhagic Escherichia coli O157:H7 in Soil and on Leaf Lettuce and Parsley Grown in Fields Treated with Contaminated Manure Composts or Irrigation Water. J. Food Prot. 2004, 67, 1365-1370. [CrossRef]

9. Hutchison, M.L.; Walters, L.D.; Moore, A.; Crookes, K.M.; Avery, S.M. Effect of length of time before incorporation on survival of pathogenic bacteria present in livestock wastes applied to agricultural soil. Appl. Environ. Microbiol. 2004, 70, 5111-5118. [CrossRef]

10. Ongeng, D.; Geeraerd, A.H.; Springael, D.; Ryckeboer, J.; Muyanja, C.; Mauriello, G. Fate of Escherichia coli O157:H7 and Salmonella enterica in the manure-amended soil-plant ecosystem of fresh vegetable crops: A review. Crit. Rev. Microbiol. 2015, 41, 273-294. [CrossRef]

11. Tran, D.T.Q.; Bradbury, M.I.; van Ogtrop, F.F.; Bozkurt, H.; Jones, B.J.; McConchie, R. Environmental drivers for persistence of Escherichia coli and salmonella in manure-amended soils: A meta-analysis. J. Food Prot. 2020, 83, 1268-1277. [CrossRef] [PubMed]

12. Warriner, K.; Huber, A. Die Off Rates of Human Pathogens in Manure Amended Soils under Natural Climatic Conditions Using a Novel Sentinel Chamber System; Technical Report; The Center for Produce Safety: Woodland, CA, USA, 2014.

13. Shah, M.K.; Bradshaw, R.; Nyarko, E.; Handy, E.T.; East, C.; Millner, P.D.; Bergholz, T.M.; Sharma, M. Salmonella enterica in soils amended with heat-treated poultry pellets survived longer than bacteria in unamended soils and more readily transferred to and persisted on spinach. Appl. Environ. Microbiol. 2019, 85, 1-14. [CrossRef] [PubMed]

14. Ongeng, D.; Muyanja, C.; Ryckeboer, J.; Geeraerd, A.H.; Springael, D. Rhizosphere effect on survival of Escherichia coli O157:H7 and Salmonella enterica serovar Typhimurium in manure-amended soil during cabbage (Brassica oleracea) cultivation under tropical field conditions in Sub-Saharan Africa. Int. J. Food Microbiol. 2011, 149, 133-142. [CrossRef] [PubMed]

15. Sharma, M.; Reynnells, R. Importance of Soil Amendments: Survival of Bacterial Pathogens in Manure and Compost Used as Organic Fertilizers. Microbiol. Spectr. 2016, 4, 1-13. [CrossRef]

16. Pang, H.; Mokhtari, A.; Chen, Y.; Oryang, D.; Ingram, D.T.; Sharma, M.; Millner, P.D.; Van Doren, J.M. A Predictive Model for Survival of Escherichia coli O157:H7 and Generic E. coli in Soil Amended with Untreated Animal Manure. Risk Anal. 2020, 40, 1367-1382. [CrossRef]

17. Nyberg, K.A.; Vinnerås, B.; Ottoson, J.R.; Aronsson, P.; Albihn, A. Inactivation of Escherichia coli O157:H7 and Salmonella Typhimurium in manure-amended soils studied in outdoor lysimeters. Appl. Soil Ecol. 2010, 46, 398-404. [CrossRef]

18. Jensen, A.N.; Storm, C.; Forslund, A.; L Baggesen, D.; Dalsgaard, A. Escherichia coli contamination of lettuce grown in soils amended with animal slurry. J. Food Prot. 2013, 76, 1137-1144. [CrossRef]

19. Ma, J.; Mark Ibekwe, A.; Crowley, D.E.; Yang, C.H. Persistence of Escherichia coli O157 and non-O157 strains in agricultural soils. Sci. Total Environ. 2014, 490, 822-829. [CrossRef]

20. Franz, E.; Semenov, A.V.; Termorshuizen, A.J.; De Vos, O.J.; Bokhorst, J.G.; Van Bruggen, A.H.C. Manure-amended soil characteristics affecting the survival of E. coli O157:H7 in 36 Dutch soils. Environ. Microbiol. 2008, 10, 313-327. [CrossRef]

21. Kothary, M.H.; Babu, U.S. Infective dose of foodborne pathogens in volunteers: A review. J. Food Saf. 2001, 21, 49-68. [CrossRef]

22. Teunis, P.; Takumi, K.; Shinagawa, K. Dose Response for Infection by Escherichia coli O157:H7 from Outbreak Data. Risk Anal. 2004, 24, 401-407. [CrossRef] [PubMed]

23. Schmid-Hempel, P.; Frank, S.A. Pathogenesis, virulence, and infective dose. PLoS Pathog. 2007, 3, 1372-1373. [CrossRef] [PubMed]

24. Ingham, S.C.; Fanslau, M.A.; Engel, R.A.; Breuer, J.R.J.E.; Breuer, J.R.J.E.; Wright, T.H.; Reith-Rozelle, J.K.; Zhu, J. Evaluation of fertilization-to-planting and fertilization-to-harvest intervals for safe use of noncomposted bovine manure in wisconsin vegetable production. J. Food Prot. 2005, 68, 1134-1142. [CrossRef] [PubMed] 
25. Jacobsen, C.S.; Bech, T.B. Soil survival of Salmonella and transfer to freshwater and fresh produce. Food Res. Int. 2012, 45, 557-566. [CrossRef]

26. Solomon, E.B.; Yaron, S.; Matthews, K.R. Transmission of Escherichia coli O157:H7 from contaminated manure and irrigation water to lettuce plant tissue and its subsequent internalization. Appl. Environ. Microbiol. 2002, 68, 397-400. [CrossRef]

27. Islam, M.; Doyle, M.P.; Phatak, S.C.; Millner, P.; Jiang, X. Survival of Escherichia coli O157:H7 in soil and on carrots and onions grown in fields treated with contaminated manure composts or irrigation water. Food Microbiol. 2005, 22, 63-70. [CrossRef]

28. Franz, E. Ecology and Risk Assessment of E. coli O157:H7 and Salmonella Typhimurium in the Primary Production Chain of Lettuce; Wageningen University: Wageningen, The Netherlands, 2007.

29. Natvig, E.E.; Ingham, S.C.; Ingham, B.H.; Cooperband, L.R.; Roper, T.R. Salmonella enterica serovar typhimurium and Escherichia coli contamination of root and leaf vegetables grown in soils with incorporated bovine manure. Appl. Environ. Microbiol. 2002, 68, 2737-2744. [CrossRef]

30. Franz, E.; Van Diepeningen, A.D.; De Vos, O.J.; Van Bruggen, A.H.C. Effects of cattle feeding regimen and soil management type on the fate of Escherichia coli O157:H7 and Salmonella enterica serovar typhimurium in manure, manure-amended soil, and lettuce. Appl. Environ. Microbiol. 2005, 71, 6165-6174. [CrossRef]

31. Fresh Produce Safety Centre Australia and New Zealand. Guidelines for Fresh Produce Food Safety; FPSC A-NZ: Camperdown, Australia, 2019.

32. Ramos, T.M.; Jay-Russell, M.T.; Millner, P.D.; Shade, J.; Misiewicz, T.; Sorge, U.S.; Hutchinson, M.; Lilley, J.; Pires, A.F.A. Assessment of Biological Soil Amendments of Animal Origin Use, Research Needs, and Extension Opportunities in Organic Production. Front. Sustain. Food Syst. 2019, 3. [CrossRef]

33. Integrated Farm Assurance: All Farm Base-Crops Base-Fruit and Vegetables-Control Points and Compliance Criteria-Version 5.1; Global G.A.P.: Cologne, Germany, 2017.

34. Bennett, R. PMA News, 2018; 1.

35. Fresh Produce Standards, Red Tractor Assurance; London, UK, 2017.

36. Commodity Specific Food Safety Guidelines for the Production and Harvest of Lettuce and Leafy Greens; California Leafy Greens Marketing Association: Sacramento, CA, USA, 2019; p. 86.

37. Chinivasagam, H.N.; Redding, M.; Runge, G.; Blackall, P.J. Presence and incidence of food-borne pathogens in australian chicken litter. Br. Poult. Sci. 2010, 51, 311-318. [CrossRef]

38. Barlow, R.S.; McMillan, K.E.; Duffy, L.L.; Fegan, N.; Jordan, D.; Mellor, G.E. Prevalence and antimicrobial resistance of salmonella and escherichia coli from Australian cattle populations at slaughter. J. Food Prot. 2015, 78, 912-920. [CrossRef]

39. Klein, M.; Brown, L.; Tucker, R.W.; Ashbolt, N.J.; Stuetz, R.M.; Roser, D.J. Diversity and abundance of zoonotic pathogens and indicators in manures of feedlot cattle in Australia. Appl. Environ. Microbiol. 2010, 76, 6947-6950. [CrossRef] [PubMed]

40. Wang, D.; Huber, A.; Dunfield, K.; Murray, K.; Wu, F.; Warriner, K. Comparative persistence of Salmonella and Escherichia coli O157:H7 in loam or sandy loam soil amended with bovine or swine manure. Can. J. Microbiol. 2018, 64, 979-991. [CrossRef] [PubMed]

41. Mcconchie, R. Remediation of Soil Contaminated by Salmonella Enterica to Expedite Plant of Replant of Vegetables; University of Sydney Faculty of Science Life and Environmental Sciences: Sydney, Australia, 2018.

42. Brennan, F.P.; Moynihan, E.; Griffiths, B.S.; Hillier, S.; Owen, J.; Pendlowski, H.; Avery, L.M. Clay mineral type effect on bacterial enteropathogen survival in soil. Sci. Total Environ. 2014, 468-469, 302-305. [CrossRef] [PubMed]

43. Phan-Thien, K.; Metaferia, M.H.; Bell, T.L.; Bradbury, M.I.; Sassi, H.P.; van Ogtrop, F.F.; Suslow, T.V.; McConchie, R. Effect of soil type and temperature on survival of Salmonella enterica in poultry manure-amended soils. Lett. Appl. Microbiol. 2020, 71, $210-217$. [CrossRef] [PubMed]

44. Cools, D.; Merckx, R.; Vlassak, K.; Verhaegen, J. Survival of E. coli and Enterococcus spp. derived from pig slurry in soils of different texture. Appl. Soil Ecol. 2001, 17, 53-62. [CrossRef]

45. Neher, D.A.; Cutler, A.J.; Weicht, T.R.; Sharma, M.; Millner, P.D. Composts of poultry litter or dairy manure differentially affect survival of enteric bacteria in fields with spinach. J. Appl. Microbiol. 2019, 126, 1910-1922. [CrossRef]

46. Chinivasagam, H.N.; Tran, T.; Blackall, P.J. Impact of the Australian litter re-use practice on Salmonella in the broiler farming environment. Food Res. Int. 2012, 45, 891-896. [CrossRef]

47. Fegan, N.; Higgs, G.; Duffy, L.L.; Barlow, R.S. The Effects of Transport and Lairage on Counts of Escherichia Coli O157 in the Feces and on the Hides of Individual Cattle. Foodborne Pathog. Dis. 2009, 6, 1113-1120. [CrossRef]

48. Çekiç, S.K.; De, J.; Jubair, M.; Schneider, K.R. Persistence of indigenous Escherichia coli in raw bovine manure-amended soil. J. Food Prot. 2017, 80, 1562-1573. [CrossRef]

49. Buchrieser, C.; Rusniok, C.; Kunst, F.; Cossart, P.; Glaser, P.; Frangeul, L.; Amend, A.; Baquero, F.; Berche, P.; Bloecker, H.; et al. Comparison of the genome sequences of Listeria monocytogenes and Listeria innocua: Clues for evolution and pathogenicity. FEMS Immunol. Med. Microbiol. 2003, 35, 207-213. [CrossRef]

50. Reed-Jones, N.L.; Marine, S.C.; Everts, K.L.; Micallef, S.A. Effects of cover crop species and season on population dynamics of Escherichia coli and Listeria innocua in soil. Appl. Environ. Microbiol. 2016, 82, 1767-1777. [CrossRef] [PubMed]

51. Locatelli, A.; Spor, A.; Jolivet, C.; Piveteau, P.; Hartmann, A. Biotic and Abiotic Soil Properties Influence Survival of Listeria monocytogenes in Soil. PLoS ONE 2013, 8, e75969. [CrossRef] [PubMed] 
52. McLaughlin, H.P.; Casey, P.G.; Cotter, J.; Gahan, C.G.M.; Hill, C. Factors affecting survival of Listeria monocytogenes and Listeria innocua in soil samples. Arch. Microbiol. 2011, 193, 775-785. [CrossRef]

53. Dowe, M.J.; Jackson, E.D.; Mori, J.G.; Bell, C.R. Listeria monocytogenes survival in soil and incidence in agricultural soils. J. Food Prot. 1997, 60, 1201-1207. [CrossRef] 